\author{
Praca poglądowa/Review paper
}

\title{
Nowotworowe komórki krążące: biologia i znaczenie kliniczne
}

\section{Cancer circulating cells: biology and clinical significance}

\author{
Wiktoria Suchorska ${ }^{1}$ \\ ${ }^{1}$ Pracownia Radiobiologii, Wielkopolskie Centrum Onkologii, Poznań, Polska
}

\section{Streszczenie}

W ostatnich latach coraz większe zainteresowanie wzbudza tzw. płynna biopsja (ang. liquidbiopsy). Płynna biopsja polega na analizie tzw. nowotworowych komórek krążących (ang. circulating tumor cells, CTC) i /lub fragmentów DNA (ang. circilating tumor DNA, ctDNA) pochodzących z komórek nowotworowych w krwi obwodowej. CTC to komórki, które przeniknęły z guza pierwotnego do światła naczyń krwionośnych i są przenoszone w organizmie w krążeniu krwi. Uważa się, że komórki te stanowią źródło rozwoju choroby metastatycznej, a ich wykrywanie i analiza może mieć znaczenie $\mathrm{w}$ prognozowaniu przebiegu rozwoju nowotworu. W niniejszej pracy przedstawiono ogólną charakterystykę nowotworowych komórek krążących z uwzględnieniem podstawowych metody ich izolacji i analizy.

\begin{abstract}
In recent years, the interest in the so-called liquid biopsy technique is growing rapidly.Liquid biopsy involves the analysis of circulating tumor cells (CTC) and / or DNA fragments (circulating tumor DNA, ctDNA) derived from cancer cells in the peripheral blood. CTCs are cells that have penetrated from the primary tumor into the lumen of blood vessels and are transferredin the body in blood circulation. It is believed that these cells are a source of metastatic disease development, and their detection and analysis may be of importance in predicting the course of cancer development. This paper presents the general characteristics of circulating cancer cells, including the basic methods of their isolation and analysis.
\end{abstract}

Słowa kluczowe: płynna biopsja, nowotoworowe komórki krążące

Keywords: liquid biopsy, circulating tumor cells

Adres do korespondencji

Wiktoria Suchorska

Pracownia Radiobiologii,

Wielkopolskie Centrum Onkologii, ul. Garbary 15, 61-866 Poznań, Polska

Telefon. +48618850 477

e-mail: wiktoria.suchorska@wco.pl 


\section{Wstęp}

Wostatnichlatach corazwiększezainteresowaniewzbudzatzw.płynnabiopsja(ang.liquidbiopsy)polegająca na analizie krążących komórek nowotworowych (ang. circulating tumor cells, CTC) i /lub fragmentów DNA (ang. circilating tumor DNA, ctDNA) pochodzących z komórek nowotworowych w krwi obwodowej(1). CTC to komórki, które przeniknęły z guza pierwotnego do światła naczyń krwionośnych i są przenoszone w organizmie w krwioobiegu. Uważa się, że komórki te stanowią źródło rozwoju choroby przerzutowej, a ich wykrywanie i analiza może mieć znaczenie w prognozowaniu przebiegu rozwoju nowotworu. CTC zostały po raz pierwszy opisane już w 1869 roku przez Thomasa Ashwortha, który postulował, że „komórki te obecne w krwi obwodowej, identyczne z komórkami guza, mogą tłumaczyć obecność wielu guzów tego samego typu u jednego chorego". Ostatnie badania potwierdzają przydatność oznaczania liczby nowotworowych komórek krążących jako narzędzia prognostycznego i markera postępu choroby.

CTC w przypadku wielu nowotworów (np. raka stercza czy raka sutka) są wykrywane zarówno u chorych na wczesnym etapie zaawansowania, jak i u tych w stadium zaawansowanym. Wykazano przydatność oznaczania liczby CTC w krwi obwodowej do przewidywania odpowiedzi klinicznej, zwłaszcza u chorych przed zastosowaniem leczenia systemowego(2). Analiza CTC po poszczególnych etapach leczenia stanowi marker odpowiedzi na zastosowaną terapię(3). Ponadto, z uwagi na fakt, że CTC są frakcją komórek pochodzącą bezpośrednio z ogniska pierwotnego, mogą one stanowić idealny model do badań in vitro biologii nowotworu(4). Rośnie liczba dowodów wskazująca na istotne znaczenie analizy CTC w diagnostyce i spersonalizowanym leczeniu raka piersi. CTC mogą przenikać do krwioobiegu przez naczynia krwionośne, które powstają na początku procesu kancerogenezy. Zwykle występują w krwi obwodowej w niewielkiej liczbie (1 na $10^{8}$ komórek jądrzastych) i mogą tam przebywać w stanie „uśpienia” (ang. dormancy) przez wiele lat. Na każdy milion komórek krążących, który jest dziennie uwalniany do krwioobiegu, blisko 90\% zanika w ciągu kilku minut, jedynie 2,5\% może utworzyć tzw. mikroprzerzuty, a tylko 0,01\% ma zdolność formowania makroprzerzutów(5).

Poza guzem pierwotnym występują także tzw. rozproszone komórki nowotworowe (ang. disseminated tumor cells, DCT), któremigrują przez układ limfatyczny i są wykrywane w większym odsetku w szpiku kostnym. Analiza populacji zarówno CTC, jak i DCT może mieć istotne znaczenie kliniczne w monitorowaniu przebiegu choroby $(2,6)$. DCT są analizowane w określonym punkcie czasowym w swoistej lokalizacji (szpik kostny), stąd wydaje się, że CTC mają większą wartość prognostyczną(7).

\section{Analiza nowotworowych komórek krążących}

CTC są izolowane z krwi obwodowej, co upraszcza procedurę uzyskania próbek, a jednocześnie umożliwia monitorowanie populacji tych komórek w czasie rzeczywistym. Zatem wydaje się, że krew obwodowa może stanowić alternatywne źródło materiału do diagnostyki chorych, a analiza liczby CTC często jest nazywana „płynną biopsją”(1). Z drugiej strony należy podkreślić, że wykrywanie CTC jest utrudnione przez niepoznaną dokładnie biologię tych komórek, która odzwierciedla heterogenność guza pierwotnego. Nawet najnowsze technologie, które zostały zastosowane do izolowania i charakterystyki CTC nadal wymagają walidacji(8). Ostatnie wyniki wskazują na związek między obecnością CTC i rozsiewem choroby, jednak w przypadku wielu nowotworów ich przydatność musi zostać potwierdzona w badaniach wieloośrodkowych.

Podczas rozwoju nowotworu niewielkie populacje komórek zlokalizowane w guzie pierwotnym (ang. primary tumour) mogą nabierać cech komórek inwazyjnych i zdolności do ruchu, a następnie przemieszczać się do światła naczyń krwionośnych Mechanizm odpowiedzialny za ten proces nie jest jeszcze dokładnie poznany, jednak postuluje się, że jest związany z interakcjami pomiędzy komórkami nowotworowymi, a otaczającą je macierzą, włączając w to odpowiedź na hipoksję (i), powstawanie przerzutów zależne od ekpresjimetaloproteinaz (ii), tworzenie nowych naczyń krwionośnych (iii) oraz nabycie cech komórek mezenchymalnych, czyli tzw. Tranzycję epitelialno - mezenchymalną (ang. epithelial - mesenchymaltransition, EMT) (iv) (9-11).

Komórki, które uległy rozsiewowi i przeżyły mogą utworzyć wtórne ognisko nowotworu w narządach odległych (np. w szpiku kostnym, płucu, wątrobie, mózgu). Komórki CTC, które opuściły światło naczyń krwionośnych zasiedlają inne organy jako DTC i zmieniają mikrośrodowisko formując nową niszę. Taka 
populacja może nabrać cech bardziej złośliwych rozwinąć się w przerzut i/lub może re-cyrkulować do innych narządów wtórnych, a nawet do ogniska pierwotnego(12). Tworzenie mikro i markoprzerzutów może zachodzić w końcowej postępu choroby, w momencie kiedy guz pierwotny osiągnął masę krytyczną i nabrał wysoce agresywnego charakteru (model liniowy), ale też często zachodzi wcześniej, kiedy ognisko pierwotne jest jeszcze stosunkowo niewielkie (model równoległy) (13). W obu przypadkach pojawienie się przerzutów wiąże się ze złym rokowaniem.

Wykrywanie nowotworowych komórek krążących, pomimo dużego postępu w dziedzinie, pozostaje nadal sporym wyzwaniem $(14,15)$. Kluczowym problemem jest wybór metody umożliwiającej wykrycie tych CTC, które są odpowiedzialne za powstawanie przerzutów. Powinna ona być połączeniem uzupełniających się technologii zoptymalizowanych pod kątem konkretnego typu nowotworu, np. raka piersi.

\section{Izolacja nowotworowych komórek krążących}

Złotym standardem wykrywania CTC jest klasyczna analiza immunocytochemiczna. Techniką najczęściej stosowaną ze względu na dostępność jest połączenie barwienia swoistym przeciciałem (np. skierowanym przeciwko cytokeratynie) z fluorescencyjną hybrydyzacjią in situ (FISH). Jednak ocena takich preparatów powinna być przeprowadzona przez specjalistę patologa i jest czasochłonna, stąd intensywny rozwój metod automatycznych, które są bardziej czułe i dokładne. Podsumowanie najważniejszych komercyjnych systemów do wykrywania CTC w krwi obwodowej chorych z wykorzystaniem technik cytometrii przepływowej przedstawiono w tabeli (tab.1, za:(16), zmodyfikowano).

Analiza populacji CTC w oparciu o metody biologii molekularnej polega głownia na zastosowaniu wariantów łańcuchowej reakcji polimerazy (ang. polymerasechainreaction, PCR). Wadą tej metody jest fakt, że za pomocą PCR można określić ilość DNA pochodzącego z CTC, ale nie można stwierdzić, czy pochodzi ono z komórek żywych, czyli takich, które zachowały zdolność tworzenia przerzutów. Problem ten rozwiązano stosując analizy w czasie rzeczywistym (ang. real-time PCR, RT-PCR), które opierają się na pomiarze poziomu ekspresji mRNA (jedynie żywe komórki mają zdolność syntezy mRNA, mRNA pochodzące z komórek apoptotycznych jest szybko degradowane). Należy jednak pamiętać, że ilość mRNA produkowana przez te same komórki jest różna w zależności od fazy cyklu komórkowego czy poziomu zróżnicowania komórek. Poza tym wysoka czułość tej metody może sprzyjać powstawaniu wyników fałszywie pozytywnych, zatem analiza populacji CTC za pomocą RT-PCR służy raczej ich charakterystyce, niż wykrywaniu(17).

Jak wspomniano liczba CTC w krwioobiegu jest stosunkowo niska (1 komórka na $10^{6}-10^{7}$ jednojądrzastych komórek krwi), stąd wstępne zagęszczenie tej populacji jest niezbędne do prawidłowego przeprowadzenia analizy(18). Metody selekcji CTC obejmują szereg technologii w zależności od cech tych komórek odróżniających je od pozostałych komórek hematopoetycznych, takich jak właściwości fizyczne (rozmiar, gęstość, ładunek elektryczny, odkształcalność) lub/i biologiczne (ekspresja białek powierzchniowych, żywotność, inwazyjność). Należy podkreślić, że większość dostępnych obecnie opiera się na analizie poziomu ekspresji białka adhezji międzykomórkowej (ang. epithelialcelladhesionmolecule,EpCAM), jednak coraz częściej analizuje się też komórki EpCAM negatywne ze względu na zjawisko EMT, któremu towarzyszy obniżenie poziomu ekspresji EpCAM CTC (patrz niżej).

Tabela 1. Wybrane metody oparte na analizie białka EpCAMstosowane do oceny populacji
CTC
\begin{tabular}{|c|c|c|c|}
\hline Test & Metoda zagęszczania & Metoda detekcji & Uwagi \\
\hline \multicolumn{3}{|c|}{ Metody oparte na analizie EpCAM } \\
\hline CellSearch@ & $\begin{array}{c}\text { Beadsyimmunomagnetyczne: } \\
\text { perełki sprzężone } \\
\text { z przeciwciałem anty-EpCAM }\end{array}$ & $\begin{array}{c}\text { Immunocytochemia: } \\
\mathrm{CK}^{+}, 18^{+}, 19^{+}, \text {CD } 45^{-}, \\
\text {DAPI }\end{array}$ & $\begin{array}{c}\text { Półautomatyczny system } \\
\text { zatwierdzony przez FDA } \\
\text { w diagnostyce raka piersi, } \\
\text { prostaty i jelita grubego }\end{array}$ \\
\hline
\end{tabular}




\begin{tabular}{|c|c|c|c|}
\hline CTC-chip & $\begin{array}{l}\text { Mikrokolumny sprzężone } \\
\text { z przeciwciałem anty-EpCAM }\end{array}$ & $\begin{array}{l}\text { Immunocytochemia: } \\
\text { CK8 } 8^{+}, \text {CK18+, CK19 } \\
\text { CD } 45^{-} \text {, DAPI }\end{array}$ & $\begin{array}{l}\text { Wysoka skuteczność } \\
\text { wykrywania (do 10o\%), } \\
\text { także u chorych Mo, brak } \\
\text { walidacji klinicznej }\end{array}$ \\
\hline $\begin{array}{l}\text { CTC-chip } \\
\text { Ephesia }\end{array}$ & $\begin{array}{l}\text { Mikrokolumny wypełnione } \\
\text { nanoperełkami sprzężonymi } \\
\text { z przeciwciałem anty-EpCAM }\end{array}$ & $\begin{array}{c}\text { Immunocytochemia: } \\
\mathrm{CK}^{+}, 18^{+}, 19^{+} \text {, CD } 45 \\
\text { DAPI }\end{array}$ & brak walidacji klinicznej \\
\hline MagSweeper & Beadsyimmunomagnetyczne & $\begin{array}{l}\text { Wizualizacja } \\
\text { mikroskopowa: } \\
\text { ocenamorfologii }\end{array}$ & $\begin{array}{l}\text { Izolacja wszystkich } \\
\text { epitelialnych komórek } \\
\text { krążących, możliwa ocena } \\
\text { w dużej objętości krwi }\end{array}$ \\
\hline Maintrack® & Liza erytrocytów & $\begin{array}{l}\text { Immunocytochemia: } \\
\text { EpCAM }^{+}, \text {CD } 45^{-} \text {, DAPI }\end{array}$ & $\begin{array}{l}\text { Wysoka wydajność oceny } \\
\text { (do } 3 \text { rzędów wielkości), } \\
\text { nieudowodniona } \\
\text { specyficzność testu }\end{array}$ \\
\hline Ikoniscope $®$ & $\begin{array}{l}\text { Wirowanie w gradiencie } \\
\text { stężeń lub filtracja }\end{array}$ & 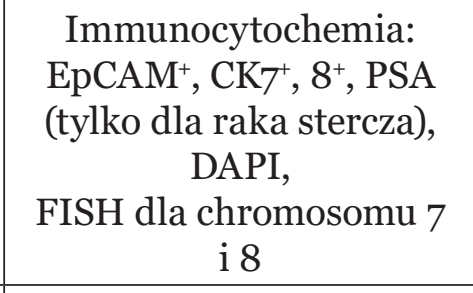 & $\begin{array}{l}\text { Dwa przeciwciała } \\
\text { skierowane swoiście przeciw } \\
\text { komórkom nabłonkowym } \\
\text { i analiza aberracji } \\
\text { chromosomowych }\end{array}$ \\
\hline Ariol $®$ & $\begin{array}{l}\text { Liza erytrocytów następnie } \\
\text { beadsyimmunomagnetyczne } \\
\text { sprzezżone z przeciwciałem } \\
\text { anty-EpCAM i anty-CK }\end{array}$ & $\begin{array}{c}\text { Immunocytochemia: } \\
\mathrm{CK}^{+}, 18^{+}, 19^{+}, \mathrm{CD} 45^{\prime} \\
\text { DAPI }\end{array}$ & $\begin{array}{l}\text { Analiza komórek CTC } \\
\text { EpCAM pozytywnych oraz } \\
\text { EpCAM negatywnych }\end{array}$ \\
\hline Anda & $\begin{array}{c}\text { Beadsyimmunomagnetyczne } \\
\text { sprzężone z anty-MUC1 } \\
\text { i EpCAM }\end{array}$ & $\begin{array}{l}\text { RT-PCR: MUC1, HER2, } \\
\text { EpCAM }\end{array}$ & $\begin{array}{l}\text { Możliwe wyniki fałszywie } \\
\text { dodatnie z powodu } \\
\text { niespecyficznej amplifikacji }\end{array}$ \\
\hline \multicolumn{4}{|c|}{ Testy funkcjonalne } \\
\hline EPISPOT & $\begin{array}{l}\text { test rozetowy, Ficoll, } \\
\text { eliminacja komórek } \\
\text { CD } 45,\end{array}$ & $\begin{array}{c}\text { Sekrecja białek CK19, } \\
\text { MUC1, Cath-D (pierś); } \\
\text { CK19 (jelito); PSA (stercz); }\end{array}$ & $\begin{array}{l}\text { Wykrywanie żywych } \\
\text { komórek nabłonkowych, } \\
\text { które zachowały zdolności } \\
\text { wydzielnicze }\end{array}$ \\
\hline
\end{tabular}




\begin{tabular}{|c|c|c|c|}
\hline Vita-Assay $^{\mathrm{TM}}$ & Zdolność do inwazji & $\begin{array}{c}\text { Immunocytochemia: } \\
\text { EpCAM }^{+}, \mathrm{ESA}^{+}, \text {pan-CK } 4^{+}, \\
5^{+}, 6^{+}, 7^{+}, 8^{+}, 10^{+}, 13^{+}, 18^{+}, \\
\text {CD } 45^{-}\end{array}$ & $\begin{array}{l}\text { Wykrywanie komórek CTC } \\
\text { o inwazyjnym fenotypie }\end{array}$ \\
\hline \multicolumn{4}{|c|}{ Pozostałe } \\
\hline ISET & Wielkość komórek & Immunocytochemia: $\mathrm{CK}^{+}$ & $\begin{array}{c}\text { Umożliwia wykrycie } 1 \\
\text { komórki/1 ml krwi; RT- } \\
\text { PCR na matrycy DNA CTC; } \\
\text { ryzyko wyników fałszywie } \\
\text { pozytywnych }\end{array}$ \\
\hline
\end{tabular}

\section{wykaz skrótów:}

Cath-D: katepsyna-D (ang. cathepsin D); CK: cytokeratyna (ang. cytokeratyn); DAPI: 4'6 - diamidyno-2fenyloindol; DEP: dielektroforeza (ang. dielectrophoresis);EpCAM: cząsteczka przylegania nabłonka (ang. epithelialcelladhesionmolecule); EPISPOT: modyfikacja metody ELISPOT umożliwiającą detekcję komórek nabłonkowych (ang. EPIthelialimmunoSPOT); ESA: antygenspecyficzny dla komórke nabłonka (ang. epithelialspecificantigen); FISH: fluorescencyjna hybrydyzacja in situ (ang. fluorescent in situ hybridization); ISET: izolacja na podstawie wielkości komórekepitelialnych (ang. isolation by size of epithelial tumor cells); MUC1: mucyna 1 (ang. mucine 1); PSA: antigen specyficzny dla stercza (ang. prostatespecificantigen); TG: tyroglobulina

Idealna metoda wykrywania CTC powinna obejmować poszukiwanie markera charakterystycznego dla komórek nabłonkowych, którego ekspresja nie obniża się w trakcie EMT i/lub takiego, typowego dla komórek mezenchymalnych, który ulega ekspresji w trakcie EMT. Ponadto ważna jest możliwość odróżnienia komórek żywych od apoptotycznych w celu wykrycia i profilowania CTC inicjujących przerzut. Wreszcie, istotne informacje mogą zostać uzyskane po ocenie wychwyconych CTC na poziomie molekularnym i porównaniu ich charakterystyki z cechami komórek ogniska pierwotnego i/lub obecnymi przerzutami. Duże zainteresowanie budzi opracowywanie urządzeń, które mogą obsługiwać próbki o objętości co najmniej dziesięciokrotnie mniejszej, niż obecnie wymagana dla bieżących testów ( $<1 \mathrm{ml}$ krwi w porównaniu z 5 do 20 $\mathrm{ml}$ ), minimalizując w ten sposób czas badania i koszty zakupu odczynników. Jednak CTC są bardzo rzadkie i analiza większych objętości krwi ( $\geq 20 \mathrm{ml}$ ) może być bardziej korzystna, szczególnie u chorych z wczesnym stadium raka. Zatem na szczególną uwagę zasługują technologie, które analizują CTC w większych objętościach próbek i ich kliniczna walidacja.

\section{Cechy biologiczne populacji nowotworowych komórek krążących utrudniające prawidłową analizę}

CTC izolowane z krwi obwodowej reprezentują heterogenną populacją komórek nowotworu ze średnim połowicznym czasem przeżycia wahającym się od 1 do 2,4 godzin (19). W krążeniu znajdują się CTC żywe i apoptotyczne, ale większość metod umożliwiających ich izolację nie rozróżnia tych dwóch populacji, podobnie, jak nie dostarcza informacji, które z komórek są aktywne w cyklu komórkowym, a które znajdują się $\mathrm{w}$ fazie $\mathrm{G}_{0}$. Pierwszym testem pozwalającym na charakterystykę CTC był EPISPOT, który wykrywa komórki CTC na podstawie ekspresji CK19 i MUC-1. Podwójne barwienie przeciwciałem skierowanym przeciwko CK19 i M30, który jest wczesnym markerem apoptozy umożliwia oszacowania komórek żywych i preapoptotycznych(20).

Natomiast poziom ekspresji białka Ki-67 związanego z proliferacją komórkową jest niski w CTC lub w ogóle nie występuje, co wskazuje na to, że większość CTC znajduje się w fazie spoczynkowej cyklu komórkowego i może być związane z opornością tych komórek na niektóre zastosowane schematy leczenia systemowego.

Analiza klasycznych markerów nabłonkowych, takich, jak EpCAM czy wybrane cytokeratyny nie jest wystarczająca do wykrycia całej populacji CTC w krwi obwodowej (21) ze względu na ich zróżnicowanie morfologiczne i molekularne (ryc. 1). 


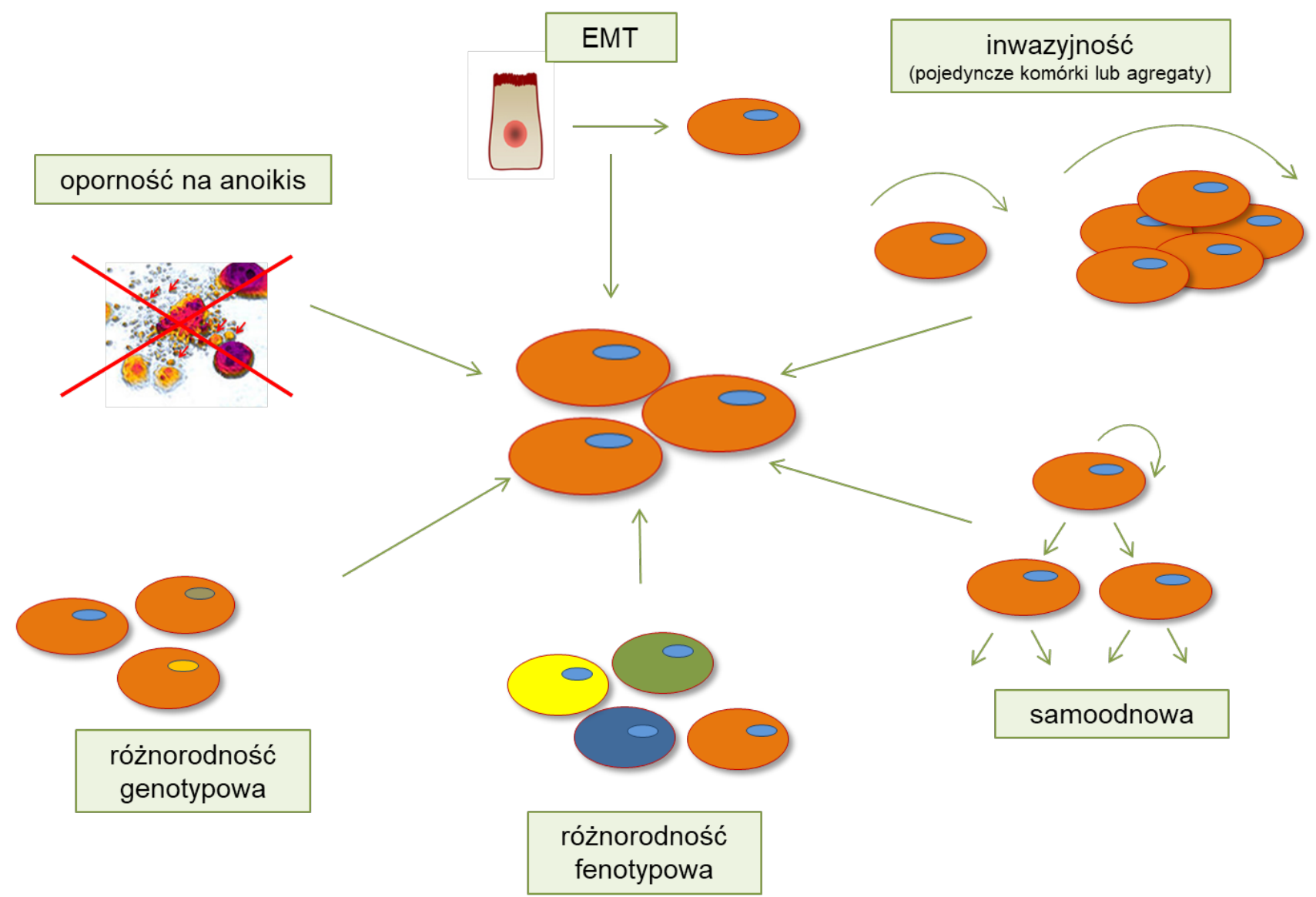

Rycina 1. Schematyczne przedstawienie najważniejszych cech charakterystycznych CTC

W dalszym ciągu nie są poznane mechanizmy unikania anoikis. Różnorodność fenotypowa CTC odnosi się nie tylko do zjawiska przejścia epitelialno-mezenchymalnego (EMT), ale obejmuje również ekspresję białek związanych z apoptozą, proliferacją, inwazją i chemotaksją i jest ściśle powiązana ze zmiennością genotypową

Wykazano, że nawet stosując metodę Cell Search ${ }^{\circledR}$, która jako jedyna jest dopuszczona do diagnostyki klinicznej przez Agencję Żywności i Leków (ang. Food and Drugs Administration, FDA) można otrzymać wyniki fałszywie negatywne, ponieważ nie zostają rozpoznane komórki zbliżone morfologiczne do zdrowych, ale jednak wykazujące cech komórek złośliwych. Dopiero zastosowanie innego markera, CD146 (ang. cluster of differentiation 146, CD146), znanego również jako cząsteczka adhezyjna komórek czerniaka (ang. melanoma celladhesionmolecule, MCAM) lub glikoproteina na powierzchni komórki MUC18, umożliwiło prawidłową ocenę populacji CTC. Za jedną z przyczyn trudności izolacji CTC w oparciu o nabłonkowe markery powierzchniowe uważa się fakt, że stosowane przeciwciała nie wykrywają szerokiego spektrum wszystkich białek powierzchniowych obecnych na komórkach(22). Badano ścieżki przekazywania sygnału przez białko EpCAM, a rezultaty tych prac częściowo tłumaczą otrzymywanie fałszywie negatywnych wyników analizy CTC w oparciu o ten marker powierzchniowy(23).Komercyjnie dostępne przeciwciała skierowane przeciw tej glikoproteinie rozpoznają tylko jego domenę zewnątrzkomórkową, podczas gdy EpCAM może być trawione przez proteazy, co z kolei prowadzi do translokacji domeny wewnątrz komórkowej do jądra komórkowego i „ukrycie” białka przed przeciwciałem. Co ciekawe, udowodniono, że komórki z wewnątrzjądrową ekspresją EpCAM mają potencjał onkogenny(23). Postuluje się, że zmienny poziom ekspresji EpCAM może być związany z okresową proliferacją CTC, która zostaje znacząco obniżona w świetle naczyń krwionośnych. Zatem guzy EpCAM pozytywne mogą uwalniać komórki, które w krwi obwodowej tracą ekspresję markerów powierzchniowych i wznawiają ją dopiero w miejscu tworzenia przerzutu.

Kolejną przyczyną utrudnionej analizy CTC w oparciu o ekspresję markerów nabłonkowych komórki jest zjawisko tranzycji epitelialno-mezenchymalnej. Komórki guza o charakterze nabłonkowym w określonych warunkach mikrośrodowiska na skutek wewnętrznych zmian lub pod wpływem bodźców zewnętrznych 
mogą przekształcać się w komórki mezenchymalne lub quasi-mezenchymalne(10), zatem ekspresja markerów nabłonkowych na tych komórkach jest niska lub niewykrywalna. Badano ekspresję genów komórek linii komórkowej wyprowadzonej z DTC izolowanych ze szpiku kostnego chorego na raka i wykazano, że posiadają one cechy charakterystyczne dla EMT, tj. relatywnie niski poziom ekspresji cytokeratyn (CK7, CK8, CK17, CK18, CK19) i wysoki poziom ekspresji wimentyny, białka związanego z fenotypem mezenchymalnym (24). Podobne wyniki uzyskano w innych eksperymentach prowadzonych niezależnie przez różne zespoły. Aktas i wsp. wykazali obecność markerów mezenchymalnych (Twist 1, Akt2 lub PI3Ka) w62\% CTC, natomiast Raimondi i wsp. udowodnili obecność dwóch markerów EMT: wimentyny i fibronektyny na komórkach CTC izolowanych z krwi obwodowej $28 \%$ chorych. U chorych, u których CTC nie wykazywały ekspresji CK ten odsetek był nawet wyższy (38\%). Badania powtórzono i potwierdzono wyniki wykonując jednoczesną analizę ekspresji tych białek w krwi obwodowej zdrowych dawców(25, 26). Jednak należy podkreślić, że chorzy otrzymujący neoadjuwantową terapię wykazują wyższy poziom ekspresji genów odpowiedzialnych za EMT(27), co jest związane z gorszym rokowaniem. Uważa się, że CTC, które ulegają EMT mogą być oporne na neoadjuwantowe leczenie, a wimentyna powinna być stosowana jako marker dodatkowy w analizie tych komórek. Warto jednak zauważyć, że wimentyna jest białkiem charakterystycznym dla subpopulacji aktywowanych monocytów, co znacząco ogranicza jej przydatność i utrudnia analizę CTC w próbkach bogatych w monocyty. Zatem konieczne staje się poszukiwanie markera związanego z EMT, który jest swoisty dla CTC.

Proces tranzycji epitelialno-mezenchymalnej i fenotyp macierzysty, którego nabierają niektóre komórki nowotworowe są ze sobą powiązane. W konsekwencji subpopulacje CTC/DTC mogą demonstrować cechy komórek macierzystych. Wykazano ekspresję białka ALDH1 uważanego za marker charakterystyczny dla komórek macierzystych w $46-70 \%$ CTC izolowanych od chorych z rakiem piersi $(25,26)$. W innych badaniach stwierdzono, że w badanej populacji CTC ponad 35\% komórek ma fenotyp CD44 $/$ CD24/low, a $17 \% \mathrm{ALDH}_{1} 1_{\mathrm{high}} / \mathrm{CD} 24^{-/ \text {low }}$ (28). Obecność nowotworowych komórek macierzystych w guzie, ich potencjał do samoodnowy i oporność na leczenie powoduje, że u chorych, u których wykryto CTC z cechami komórek macierzystych częściej dochodzi do niepowodzenia terapii(25). Stwierdzono, że w 86\% CTC izolowanych od pacjentek z przerzutującym rakiem piersi występuje nadekspresja jednego lub więcej białek związanych $\mathrm{z}$ odpornością wielolekową (ang. multi-drugresistance-related protein, MRP), co jest związane $\mathrm{z}$ istotnym skróceniem czasu przeżycia (ang. overallsurvival, OS).

Diagnostyka molekularna chorych na nowotwory opiera się przede wszystkim na analizie ogniska pierwotnego, jednak w masie guza znajdują się zarówno komórki inwazyjne, jak i nieinwazyjne. Z klinicznego punktu widzenia w ocenie ryzyka nawrotu choroby znaczenie mają tylko te pierwsze(29). CTC stanowią populację komórek, które już rozprzestrzeniły się w organizmie i mają potencjał tworzenia przerzutów. Różnice pomiędzy CTC, a komórkami guza pierwotnego występują stosunkowo często, mogą wpływać na odpowiedź chorego na terapię, której schemat nie uwzględnia fenotypu komórek krążących (30). Wykazano obecność w krwi obwodowej CTC HER-2 pozytywnych, pomimo zdiagnozowania u chorych raka piersi HER2, notowano także sytuacje odwrotne, podobnie rozbieżności dotyczyły ekspresji receptora estrogenowego, progesteronowego, czy EGFR, których poziom ekspresji ma istotne znaczenie w kwalifikowaniu chorych do konkretnej terapii(30-33). To zjawisko można wytłumaczyć ograniczeniami dostępnych metod eksperymentalnych, które np. pomijają w ocenie niewielkie, ale istotne kliniczne klony komórek guza pierwotnego. Pojawia się też postulat, że CTC podlegają silnej selekcji w trakcie przenikania do światła naczyń krwionośnych, rozsiewu lub na skutek zastosowanego leczenia ogólnoustrojowego i ich niestabilność genomowa może prowadzić do wytworzenia nowych klonów komórek nowotworowych o cechach fenotypowych/genotypowych różniących się od cech pierwotnych komórek nowotworowych. Dodatkowo CTC izolowane z krwi obwodowej mogą pochodzić z ogniska przerzutowego i ich fenotyp/genotyp może odpowiadać komórkom budującym przerzut (12).

\section{Podsumowanie}

Płynna biopsjado oceny nowotworowych komórek krążących w krwi chorego wydaje się być obiecującym testem służącym do wczesnego wyrycie mikroprzerzutów. Wstępne wyniki są zachęcające, jednak w celu oszacowania klinicznej użyteczności CTC, jako niezależnego biomarkera niezbędne są wieloośrodkowe 
badania obejmujące większe grupy chorych, dłuższe okresy obserwacji, bardziej szczegółową charakterystykę molekularną CTC i walidowaneprocedury. Przyszłe analizy powinny koncentrować się na biologii CTC i pokazać, czy zmiany ich liczebności i właściwości mogą ułatwić przewidywanie odpowiedzichorego na określone terapie, a tym samym uzupełnić obecne testy diagnostyczne.

\section{Bibliografia}

[1] Pantel K, Alix-Panabieres C. Circulating tumour cells in cancer patients: challenges and perspectives. Trends Mol Med. 2010;16(9):398-406.

[2] Cristofanilli M, Budd GT, Ellis MJ, Stopeck A, Matera J, Miller MC, et al. Circulating tumor cells, disease progression, and survival in metastatic breast cancer. N Engl J Med. 2004;351(8):781-91.

[3] Ascolani G, Occhipinti A, Lio P. Modelling circulating tumour cells for personalised survival prediction in metastatic breast cancer. PLoS Comput Biol. 2015;11(5):e1004199.

[4] Giuliano M, Herrera S, Christiny P, Shaw C, Creighton CJ, Mitchell T, et al. Circulating and disseminated tumor cells from breast cancer patient-derived xenograft-bearing mice as a novel model to study metastasis. Breast Cancer Res. 2015;17:3.

[5] Park Y, Kitahara T, Urita T, Yoshida Y, Kato R. Expected clinical applications of circulating tumor cells in breast cancer. World J Clin Oncol. 2011;2(8):303-10.

[6] Braun S, Vogl FD, Naume B, Janni W, Osborne MP, Coombes RC, et al. A pooled analysis of bone marrow micrometastasis in breast cancer. N Engl J Med. 2005;353(8):793-802.

[7] Balic M, Lin H, Williams A, Datar RH, Cote RJ. Progress in circulating tumor cell capture and analysis: implications for cancer management. Expert Rev Mol Diagn. 2012;12(3):303-12.

[8] Wicha MS, Hayes DF. Circulating tumor cells: not all detected cells are bad and not all bad cells are detected. J Clin Oncol. 2011;29(12):1508-11.

[9] Bonnomet A, Brysse A, Tachsidis A, Waltham M, Thompson EW, Polette M, et al. Epithelial-tomesenchymal transitions and circulating tumor cells. J Mammary Gland Biol Neoplasia. 2010;15(2):26173.

[10] Chaffer CL, Weinberg RA. A perspective on cancer cell metastasis. Science. 2011;331(6024):1559-64.

[11] Hanahan D, Weinberg RA. Hallmarks of cancer: the next generation. Cell. 2011;144(5):646-74.

[12] Comen E, Norton L, Massague J. Clinical implications of cancer self-seeding. Nat Rev Clin Oncol. 2011;8(6):369-77.

[13] Klein CA. Parallel progression of primary tumours and metastases. Nat Rev Cancer. 2009;9(4):302-12.

[14] Cho H, Kim J, Song H, Sohn KY, Jeon M, Han KH. Microfluidic technologies for circulating tumor cell isolation. Analyst. 2018;143(13):2936-70.

[15] Sharma S, Zhuang R, Long M, Pavlovic M, Kang Y, Ilyas A, et al. Circulating tumor cell isolation, culture, and downstream molecular analysis. Biotechnol Adv. 2018;36(4):1063-78.

[16] Bednarz-Knoll N, Alix-Panabieres C, Pantel K. Clinical relevance and biology of circulating tumor cells. Breast Cancer Res. 2011;13(6):228.

[17] Lianidou ES, Markou A. Circulating tumor cells in breast cancer: detection systems, molecular characterization, and future challenges. Clin Chem. 2011;57(9):1242-55.

[18] Broersen LH, van Pelt GW, Tollenaar RA, Mesker WE. Clinical application of circulating tumor cells in breast cancer. Cell Oncol (Dordr). 2014;37(1):9-15.

[19] Meng S, Tripathy D, Frenkel EP, Shete S, Naftalis EZ, Huth JF, et al. Circulating tumor cells in patients with breast cancer dormancy. Clin Cancer Res. 2004;10(24):8152-62.

[20] Rossi E, Basso U, Celadin R, Zilio F, Pucciarelli S, Aieta M, et al. M3o neoepitope expression in epithelial cancer: quantification of apoptosis in circulating tumor cells by CellSearch analysis. Clin Cancer Res. 2010;16(21):5233-43.

[21] Konigsberg R, Obermayr E, Bises G, Pfeiler G, Gneist M, Wrba F, et al. Detection of EpCAM positive and negative circulating tumor cells in metastatic breast cancer patients. Acta Oncol. 2011;50(5):700-10.

[22] Effenberger KE, Borgen E, Eulenburg CZ, Bartkowiak K, Grosser A, Synnestvedt M, et al. Detection and clinical relevance of early disseminated breast cancer cells depend on their cytokeratin expression pattern. Breast Cancer Res Treat. 2011;125(3):729-38. 
[23] Maetzel D, Denzel S, Mack B, Canis M, Went P, Benk M, et al. Nuclear signalling by tumour-associated antigen EpCAM. Nat Cell Biol. 2009;11(2):162-71.

[24] Bartkowiak K, Wieczorek M, Buck F, Harder S, Moldenhauer J, Effenberger KE, et al. Two-dimensional differential gel electrophoresis of a cell line derived from a breast cancer micrometastasis revealed a stem/ progenitor cell protein profile. J Proteome Res. 2009;8(4):2004-14.

[25] Aktas B, Tewes M, Fehm T, Hauch S, Kimmig R, Kasimir-Bauer S. Stem cell and epithelial-mesenchymal transition markers are frequently overexpressed in circulating tumor cells of metastatic breast cancer patients. Breast Cancer Res. 2009;11(4):R46.

[26] Raimondi C, Gradilone A, Naso G, Vincenzi B, Petracca A, Nicolazzo C, et al. Epithelial-mesenchymal transition and stemness features in circulating tumor cells from breast cancer patients. Breast Cancer Res Treat. 2011;130(2):449-55.

[27] Mego M, Mani SA, Lee BN, Li C, Evans KW, Cohen EN, et al. Expression of epithelial-mesenchymal transition-inducing transcription factors in primary breast cancer: The effect of neoadjuvant therapy. Int J Cancer. 2012;130(4):808-16.

[28] Theodoropoulos PA, Polioudaki H, Agelaki S, Kallergi G, Saridaki Z, Mavroudis D, et al. Circulating tumor cells with a putative stem cell phenotype in peripheral blood of patients with breast cancer. Cancer Lett. 2010;288(1):99-106.

[29] Suchorska WM ZK. Budowa guza nowotworowego, w: Planowanie leczenia i dozymetria w radioterapii. T. 1. red. Malicki J, Ślosarek K, . 2016:298-306.

[30] Munzone E, Nole F, Goldhirsch A, Botteri E, Esposito A, Zorzino L, et al. Changes of HER2 status in circulating tumor cells compared with the primary tumor during treatment for advanced breast cancer. Clin Breast Cancer. 2010;10(5):392-7.

[31] Gradilone A, Naso G, Raimondi C, Cortesi E, Gandini O, Vincenzi B, et al. Circulating tumor cells (CTCs) in metastatic breast cancer (MBC): prognosis, drug resistance and phenotypic characterization. Ann Oncol. 2011;22(1):86-92.

[32] Aktas B, Muller V, Tewes M, Zeitz J, Kasimir-Bauer S, Loehberg CR, et al. Comparison of estrogen and progesterone receptor status of circulating tumor cells and the primary tumor in metastatic breast cancer patients. Gynecol Oncol. 2011;122(2):356-60.

[33] Riethdorf S, Muller V, Zhang L, Rau T, Loibl S, Komor M, et al. Detection and HER2 expression of circulating tumor cells: prospective monitoring in breast cancer patients treated in the neoadjuvant GeparQuattro trial. Clin Cancer Res. 2010;16(9):2634-45. 